University of Michigan Law School University of Michigan Law School Scholarship Repository

Articles

Faculty Scholarship

1998

\title{
Lesbian Divorce: A Commentary on the Legal Issues
}

David L. Chambers

University of Michigan Law School, dcham@umich.edu

Available at: https://repository.law.umich.edu/articles/1048

Follow this and additional works at: https://repository.law.umich.edu/articles

Part of the Family Law Commons, and the Sexuality and the Law Commons

\section{Recommended Citation}

Chambers, David L. "Lesbian Divorce: A Commentary on the Legal Issues." Am. J. Orthopsychiatry 68, no. 3 (1998): 420-3.

This Article is brought to you for free and open access by the Faculty Scholarship at University of Michigan Law School Scholarship Repository. It has been accepted for inclusion in Articles by an authorized administrator of University of Michigan Law School Scholarship Repository. For more information, please contact mlaw.repository@umich.edu. 


\title{
Lesbian Divorce: A Commentary on the Legal Issues
}

\author{
David L. Chambers, J.D.
}

Lest esbian couples who break up will find themselves in an awkward position under the law for two separable but related reasons. The first is that, because they were unmarried, they are subjected by the law to much the same uneven and ambivalent treatment to which unmarried heterosexual couples are subjected. The second, of course, is that they are gay or lesbian and thus regarded with special disfavor even in some states that have become more tolerant of unmarried heterosexual relationships.

As a law teacher who is gay and who writes about family law issues relating to gay men and lesbians, I have prepared this brief piece, drawing in part on an earlier article of mine (Chambers, 1996), to elaborate on the legal issues raised by Morton (1998, this issue). In nearly all respects the points made here apply in full to gay male couples who are separating, but, like Morton, I will use lesbian couples in my examples.

\section{FINANCIAL ISSUES}

When opposite-sex couples divorce after a legally recognized marriage, all states impose rules for the division of property accumulated during the marriage. The rules differ considerably among the states but, in the great majority, courts today assume as a starting point that the divorcing couple will split the marital property fifty-fifty. Assets subject to division include not merely such obvious tangible resources as the equity in a home purchased during the marriage or moneys in a checking account, but also asyet-unreachable funds building up in a pension account. For the long-married couple, in which one spouse has worked in the labor force and the other has not, or in which one spouse earns vastly more than the other, courts in most states will also award periodic payments of alimony for a fixed or indefinite number of years. As Morton correctly points out, divorce commonly leaves one or both spouses economically worse off than they had been when living together, but married persons can at least count on the state to order some division of assets between them.

How, by comparison, does the law treat the income and assets of unmarried persons in a long-term couple relationship? Very differently indeed, although again the rules vary widely among the states. Prior to the last 30 years or so, courts in nearly all states refused to intervene in the separation of unmarried opposite-sex couples, on the grounds that the relationship itself was immoral. This held true even in cases in which the unmarried partners had agreed to share assets. A few states retain this approach today.

In most states, however, the law has changed, responding to the huge growth in the numbers of cohabiting unmarried opposite-sex couples and to the increased social acceptance of such cohabitation. Courts do not treat long-term unmarried partners the same as they treat married partners but, in most states, if a couple has entered into a formal agreement to divide property or provide mutual support, it will now be enforced by the courts. A few states have gone further, coming somewhat closer to imposing the rules for divorcing married couples. Some will enforce "implied contracts," the contents of which they infer not from actual words of agreement of the parties but from the parties' conduct in, for example, sharing income and expenses. A few more states will, at the request of a longterm unmarried partner, simply impose a property division that seems "just" to the court, even in the absence of any express or implied agree- 
ment between the parties. In most states, however, unmarried partners still have no stateprescribed obligations to each other that apply in the absence of a contractual agreement about what will happen on separation. Each can walk away, taking whatever is titled in his or her name.

Are even these limited protections available to partners in a same-sex relationship? There have been surprisingly few appellate decisions in cases involving property disputes between gay male or lesbian partners who are separating. In a few states, such as California, courts have made clear that express agreements between unmarried same-sex couples are as enforceable as those between their opposite-sex counterparts. In other states, however, lesbians or gay men going through separation face the possibility that courts will treat their relationships less favorably than those of other unmarried couplesi.e., that the courts will regard same-sex but not opposite-sex unmarried relations as immoral.

\section{PARENTING ISSUES}

Lesbian couples come to share the parenting of a child in at least three quite different ways. The first occurs when a woman who has had a child in the course of a prior relationship, often in a prior marriage with a man, begins to live with a woman, and that woman joins in the care of the child. The new partner becomes the functional equivalent of a "stepparent." Second, and increasingly common today, are relationships in which a lesbian couple after beginning to live together decides to have a child and agrees that one of them will be the biological mother and the other will serve as an equal co-parent. (In some of these cases, but far from all, the nonbiological parent formally adopts the child born to her partner.) The third context occurs when a lesbian couple adopts a child who is biologically related to neither of them, or when one of them adopts a child and the other serves as coparent.

Under any of these kinds of parenting arrangements, what happens when the lesbian couple separates? Will the woman who is not the biological mother or who has not formally adopted the child be eligible to be considered for custody? Will she be eligible for courtordered visitation? Will she be subject to an order compelling her to pay child support? In the great majority of states, the answer to these questions is clear: unless the nonbiological "moth- er" has formally adopted the child, she will have no legally enforceable rights or duties; she will not be eligible for court-ordered custody or visitation and not obligated to provide support. This will be true in the great majority of states no matter how long the nonbiological mother lived with and helped care for the child, and no matter what the understanding was between the women about their shared parenting undertaking. (In cases in which the child was born of a prior relationship of the biological mother with a man, the father will be the one who has rights of visitation and obligations to pay child support.)

The situation ought to be quite different for a couple when the nonbiological parent has formally adopted her partner's biological child as a second legal parent. Courts in a growing number of states permit such adoptions when there is no biological father asserting rights of parenting. Morton expresses concern about the position of the adoptive mother in such cases. As a legal matter, Morton ought to be wrong. If the nonbiological mother has actually adopted the child, then, upon separation, the two parents should stand as equals-equally entitled to be considered for custody and visitation and equally obligated to pay child support if the child is living with the other parent. I have found no cases whatever in which an adoptive lesbian mother has been treated badly in the courts at the time of a separation. Still, Morton may prove correct in some instances; it is certainly true that a judge who disapproved of the relationship between two women might acknowledge that both parents were legal equals but stretch to find ways to conclude that the child's best interests would be served by curtailing contact with the adoptive parent.

\section{MARRIAGE AND DOMESTIC PARTNERSHIP}

Many lesbians and gay men are waiting eagerly for the final resolution of a case in which the Hawaiian Supreme Court may well hold that same-sex couples are constitutionally entitled to marry in Hawaii on the same terms as oppositesex couples. If Hawaii does permit same-sex couples to marry, then, at least in Hawaii, the rules regarding marriage and divorce that apply to opposite-sex married couples will presumably apply in full to same-sex couples. On separating, they will be entitled to fight by the same formal rules heretofore reserved for unhappy heterosexual couples. At the time of this writ- 
ing, similar cases are also pending in Alaska and Vermont.

But, even in Hawaii, Alaska, and Vermont, the state supreme courts may reject the constitutional claims or the states' legislatures or voters may amend their constitutions to limit marriage to opposite-sex couples. No state legislature has seriously considered legislation to grant lesbian and gay couples the right to marry. Indeed, a substantial number of legislatures, fearing the outcome in Hawaii, have recently passed laws explicitly declaring that only opposite-sex marriages will be recognized within their jurisdictions, directing their courts not only to refuse same-sex couples the right to marry but also to refuse to recognize the marriage of a same-sex couple validly married in another state. This effort has been given the support of the U.S. Congress, which in 1996 passed the Defense of Marriage Act, declaring that no state is required to recognize a same-sex marriage adopted in another state.

If any movement toward the general recognition of same-sex couples does occur, it is likely to be through legislation that permits couples to register with the state as "domestic partners" and receive some but not all of the benefits of married persons. Denmark, Norway, and Iceland, for example, all permit same-sex couples to register their relationships with the state and become subject to all the financial rules that apply to married persons (including the rules that apply at divorce). They do not, however, treat same-sex couples as equals for purposes of access to adoption or other parenting benefits. Hawaii's legislature has recently adopted domestic partner registration, extending to unmarried couples some of the rights of married couples, but no other state has moved to do so. An increasing number of cities and private employers are extending health and other benefits to the same-sex partners of their employees, and while some cities (e.g., San Francisco and Chicago) permit same-sex couples to register their relationships, these local ordinances, although important symbolically, typically carry no legal consequences.

\section{ADVANCE PLANNING}

Given the current state of the law, what should lesbians in couples do to protect themselves? I am a teacher, not a practicing attorney, but the primary piece of advice passed along to me by legal colleagues who regularly work with lesbian and gay couples is: Plan ahead! While a couple is still a couple, the two partners should talk about what they wish to have happen if they should split at some unforeseen future time. The conversation is likely to be awkward, but it may help reduce later serious misunderstandings if there is a break-up.

Such conversations are generally valuable for all couples, but they are especially important for same-sex couples. Because we cannot marry under the law today, lesbian and gay people who live together are necessarily in a different, more ambiguous and precarious situation than heterosexual couples. Some individuals in samesex couples regard themselves as married; without thinking very carefully about it, they may assume that if they were to separate, they would divide their property much as a married couple would. Others prize independence, financial and otherwise, and would not choose to marry even if they were legally permitted to do so. Sometimes, sad to say, one member of a samesex couple holds the first of these views while the other maintains the second; although each may sense the other's dissonant position, the two of them never directly discuss their hopes or expectations until a point of crisis, when neither is thinking particularly clearly. Morton's article does well to remind us of all the reasons why lesbians (and gay men) can have conflicting perceptions as they go through the process of separation.

As for finances, I would advise same-sex couples to draw up in advance an agreement about who will get what on separation. If there are substantial assets-particularly if one of them owns a home in which they both live-an attorney can help them reach an understanding about their financial position while they are together. And while they are together, they should determine how they will divide property that they buy together during their relationship and property that accumulates in the name of one of them. Some coupled persons will wish to merge everything-even agreeing to share the value of pension rights accruing in the individual name of one of them. Others will want to keep most assets separate. After reaching such an agreement, the couple would be well advised to return to it from time to time, and ask whether it continues to meet the needs and expectations of both partners.

With even greater fervor, I advise careful advance legal planning for couples who wish to 
have or to adopt a child together. If neither partner intends to be the child's biological mother, the couple will first want to learn whether it is legally permissible to adopt as a couple, or whether only one of them will be permitted to adopt. If, on the other hand, one partner is going to be the biological mother, then the initial step in planning is to learn whether, in their state, legal adoption is possible for a nonbiological parent figure. If so, the couple must then confront directly whether both partners want the nonbiological mother to be a full and equal legal parent. Faced honestly, this question may not be easy for the biological mother to answer, for some women who bear a child may want to share the caretaking but still preserve their legal advantage. If that is so, the partner (at least in my view) ought to know about it.

If adoption is not possible, I would encourage those who undertake parenting to reach a formal written understanding about what they expect if they break up-not necessarily fixing specific custody arrangements (they may well not be able to foresee what will be best for the child or for either of them some years later) but at least memorializing an understanding about whether, and to what general extent, the nonbiological mother is to be eligible to continue a relationship with the child. Such an agreement will probably not be enforceable in court, but most people who voluntarily enter into agreements feel a moral obligation to live up to them. Further, the prospect of lesbian friends pressing the two partners to live up to their actual agreement seems less troubling than does Morton's account of lesbian friends pressing partners who have never had an agreement simply to be kind and decent or politically correct.

Both couples who write agreements in advance and those who do not should also consider ways of resolving disputes that do not involve the courts. This applies to all couples, but especially to lesbians and gay men, because we cannot be certain of the reactions of judges to our life situations. Thus, couples who draft agreements should include a provision for turning to a neutral third person to help them mediate a resolution of any dispute. Similarly, those who have split up but have no written agreement should also consider seeking out a neutral mediator if they are unable to come to a resolution between themselves.

\section{THE CLINICIAN AND THE LAW}

A final and general piece of advice for therapists who treat lesbians and gay men is that they would be wise to learn somewhat more than has been conveyed here about the legal context in which their gay patients live their lives. State laws vary widely and, even within states, judges and agencies have wide discretion and use it in widely differing ways. Clinicians should make an effort to learn somewhat more both about state rules and the practices of the judges and agencies (such as adoption agencies) in their particular part of the state.

The reason for learning about the law is not to be in a position to offer legal advice, but for the two-fold value of understanding clients better when the clients describe the legal positions in which they find themselves, and being able to alert clients about potential legal problems that the clients may have not considered. If a lesbian client with a partner tells a therapist that she is planning to become pregnant, the therapist could appropriately ask whether she and her partner have discussed the legal consequences of the decision for them both and point her in the direction of obtaining assistance.

So, my concluding advice is: Take a lawyer to lunch. Split the tab. She has as much or more to learn from you as you have from her.

\section{REFERENCES}

Chambers, D. (1996). What if? The legal consequences of marriage and the legal needs of lesbian and gay male couples. Michigan Law Review, 95, 447-491.

Morton, S.B. (1998). Lesbian divorce. American Journal of Orthopsychiatry, 68, 410-419. 